University of Nebraska - Lincoln

DigitalCommons@University of Nebraska - Lincoln

1987

\title{
Early Fur Trade on the Northern Plains: Canadian Traders among the Mandan and Hidatsa Indians, 1738-1818.
}

James A. Hanson

Lincoln, Nebraska

Follow this and additional works at: https://digitalcommons.unl.edu/greatplainsquarterly

Part of the Other International and Area Studies Commons

Hanson, James A., "Early Fur Trade on the Northern Plains: Canadian Traders among the Mandan and Hidatsa Indians, 1738-1818." (1987). Great Plains Quarterly. 333.

https://digitalcommons.unl.edu/greatplainsquarterly/333

This Article is brought to you for free and open access by the Great Plains Studies, Center for at DigitalCommons@University of Nebraska - Lincoln. It has been accepted for inclusion in Great Plains Quarterly by an authorized administrator of DigitalCommons@University of Nebraska - Lincoln. 
Early Fur Trade on the Northern Plains: Canadian Traders among the Mandan and Hidatsa Indians, 1738-1818. Edited and with an introduction by W. Raymond Wood and Thomas D. Thiessen. Norman: University of Oklahoma Press, 1985. Maps, illustrations, tables, bibliography, index. $\mathrm{xx}+354$ pp. $\$ 29.95$.

The permanent villages of farming Indians on the Upper Missouri were a central focus for trade in prehistoric times. By the beginning of the eighteenth century, both French and Spanish traders had reached the area, and by the early nineteenth century, the MandanHidatsa villages had come to be a Parisian entrepot for the buffalo hunting tribes, the St. Louis and Canadian traders, and the artists and explorers of young America. While the drive up the Missouri from St. Louis is well documented, Wood and Thiessen have unveiled for us an exciting story of the important and early Canadian connection of North Dakota's Mandan-Hidatsa towns.

The book has two major parts. First, a brilliant and concise introduction gives us a history of the Canadian-Missouri River trade and explanations of how and why the trade was conducted. A concluding chapter is the best synopsis yet written of the tragic MandanHidatsa collapse from disease and warfare. The second section is a wonderful retranscription of the narratives of John Macdonell, David Thompson, Francois-Antoine Larocque, and Charles McKenzie, sweeping clean transla- tions, transcriptions, and expurgations that had rendered these journals more hindrance than help to scholars. The new transcriptions are chock full of exciting ethnographic and historical information. These narratives document visits by North West Company employees to the Upper Missouri predating or contemporary with the fabled Lewis and Clark expedition. They delineate the intense competition of the Hudson's Bay Company and provide some important insights into the Indians' side of meeting the American captainexplorers.

The editing is precise and professional. Each of the narratives is preceded by an interpretive introduction which sets forth a synopsis of the author's life, the history of the manuscript itself, and various useful technical data which help to authenticate and date the transcribed material. Each journal has excellent annotations along with editorial corrections and original pagination.

Reading and transcribing faded nineteenth century manuscripts in the antiquated hands of different scriveners is at best an unenviable task. Wood and Thiessen have expended tremendous effort to produce new, more precise copies of the journals. Despite the obvious care involved, there seem to be some mistranscriptions. For example, in Larocque's "Yellowstone Journal" (page 215), the ends of the Indians' leggings should probably be "tucked" rather than "tacked" in their belts, and they are probably wearing "leather" as opposed to the recorded "feather" belts.

The book is appointed with thirteen carefully selected illustrations including site photographs, trade goods, original documents, and topographic details. There are three excellent maps and six superb tables covering such subjects as documented Canadian fur trade trips to the North Dakota Indian villages, types of trade goods being sold, and applicable trading post inventories.

All in all, it is easy to commend the editors and to give a congratulatory nod to the University of Oklahoma Press. I unhesitatingly recommend this volume to Plains archeolo- 
gists, anthropologists, and historians, but it should have a far wider audience. Its quality of research, data, and production will make it a professional standard.

JAMES A. HANSON

Nebraska State Historical Society

Lincoln, Nebraska 